\title{
Cechy systemów fonologicznych muzyki i mowy z perspektywy ewolucyjnej
}

\section{Characteristics of the phonological systems of music and speech from an evolutionary perspective}

\author{
Piotr Podlipniak \\ INSTYTUT MUZYKOLOGII, UNIWERSYTET IM. ADAMA MICKIEWICZA \\ Ul. UMULTOWSKA 89D, 61-614 POZNAŃ \\ podlipeamu.edu.pl
}

\begin{abstract}
This article presents the phonological systems of music and speech as two different Humboldt systems which evolved for different reasons. The mental and the intersubjective characteristics of both systems are presented, including the relations between music and speech and the respective conceptual mental representations. The main aim of this paper is to suggest that the phonological system of music evolved earlier than articulated speech. As a result, the phonological system of speech emerged as a connection between two existing mental mechanisms, one that enabled our ancestors to use the Humboldt system in the domain of vocal communication and another which allowed them to combine referential meaning with sound symbols.
\end{abstract}

\section{Wprowadzenie: muzyka i mowa jako systemy fonologiczne}

Spośród licznych naturalnych form komunikacji wokalnej człowieka tylko śpiew i mowa - wokalne realizacje odpowiednio muzyki i języka naturalnego - charakteryzują się własnościami, które umożliwiają tworzenie nieograniczonej liczby złożonych komunikatów za pomocą zestawiania ograniczonej liczby jednostek (Merker 2002). Jest to możliwe, ponieważ jednostki te (klasy wysokości dźwięku o określonej wartości rytmicznej w muzyce (Bielawski 1968) oraz fonemy w mowie (Berent 2012)) mają charakter dyskretny. $Z$ jednostek tych tworzone są większe 
Piotr Podlipniak: Cechy systemów fonologicznych muzyki i mowy z perspektywy ewolucyjnej

całości (np. motywy, frazy, tematy muzy czne czy morfemy, słowa, zdania) $\mathrm{w}$ oparciu o charakterystyczne dla danej muzyki ${ }^{1}$ czy mowy reguły. Zarówno mowa (Berent 2012) jak i muzyka (Tillmann, Bharucha i Bigand 2000; Opacic, Stevens i Tillmann 2009) nabywane są w sposób implicytny na wczesnych etapach ontogenezy człowieka (Brandt, Gebrian i Slevc 2012) i stają się częścią naturalnego behawioru dojrzałych ludzi. Mimo istnienia pewnych podobieństw pomiędzy muzyką i mową a ekspresjami wokalnymi zaobserwowanymi jak dotąd u niektórych gatunków ptaków (Fitch i Jarvis 2013; Okanoya 2013; Rothenberg i wsp. 2014) i ssaków (Payne 2000), wszystkie znane formy ekspresji wokalnej innych niż człowiek gatunków zwierząt nie wykazują w świetle obecnej wiedzy złożoności jaką charakteryzuje się kompozycjonalność muzyki i mowy (Fitch i Jarvis 2013). Muzyka i mowa stanowią zatem naturalne, gatunkowo specyficzne systemy fonologiczne człowieka, a ich charakterystyka (kombinatoryczność ograniczonej liczby dyskretnych jednostek) odpowiada cechom tzw. systemu Humboldta (Merker 2002).

\section{Systemy fonologiczne mowy i muzyki jako zjawiska mentalne}

Mimo że zarówno $\mathrm{w}$ mowie jak i muzyce środkiem transmisji informacji jest dźwięk, wspomniana dyskretność podstawowych segmentów muzycznych i mownych ma charakter mentalny (intersubiektywny), a nie akustyczny (obiektywny), gdyż opiera się na interpretacji dźwięków przez układ nerwowy człowieka na podstawie jedynie wybranych, specyficznych dla danej muzyki czy mowy, cech bodźca akustycznego (Berent 2012; Huron 2016; Patel 2003; Purves 2017). Oznacza to, że komunikacja pomiędzy osobnikami posługującymi się mową i muzyką odbywa się dzięki synchronizacji mentalnej (por. Bharucha, Curtis i Paroo 2011) owych dyskretnych kategorii, generowanych poprzez percepcję wybranych parametrów akustycznych percypowanych bodźców. W przypadku muzyki parametrami akustycznymi, które w głównej mierze wpływają na dyskryminację dyskretnych jednostek kodu muzycznego są częstotliwość tonu podstawowego dźwięku o strukturze harmonicznej $\left(\mathrm{F}_{\mathrm{o}}\right.$ ) (Stainsby i Cross 2008; Rakowski 2009) oraz odstęp czasu pomiędzy następującymi po sobie dźwiękami (ang. IOI - inter-onset-interval) (Jones 2009). Parametry te wpływają odpowiednio na rozpoznanie klasy wysokości (np. dźwięku $c$ lub $a$ we współczesnym zachodnim systemie muzycznym) oraz wartości rytmicznej (np. półnuty czy ćwierćnuty także we współczesnym zachodnim systemie muzycznym) sły szanego dźwięku. Cecha wrażeniowa, jaką jest wysokość dźwięku doświadczana może być jednak dwojako (Deutsch, Dooley i Henthorn 2008). Bądź jako wrażenie wysokości

\footnotetext{
1 Istnieja wprawdzie we współczesnej kulturze muzycznej takie rodzaje muzyki, głównie awangardowej, które nie spełniają wskazany ch wy żej kry teriów. Ponieważ jednak zjawiska te ograniczone są swym zasięgiem historyczno-kulturowym jedynie do dwudziesto- i dwu dziestopierwszowiecznej kultury muzy cznej Zachodu, a w ramach tej kultury współegzy stują z innymi rodzajami muzyki i cieszą się zainteresow aniem jedynie wąskich elit (Dutton 2009), zostały tu pominięte jako niereprezentaty wne dla gatunku Homo sapiens.
} 
zmieniającej się w sposób ciągły, jak ma to miejsce podczas słuchania intonacji mowy, bądź w kategoriach dyskretnych klas wysokości dźwięku podczas słuchania muzyki. Co więcej te same parametry akustyczne mogą być interpretowane przez układ nerwowy człowieka różnie w zależności od rozmaitych okoliczności percepcyjnych. Okazuje się, że układ nerwowy człowieka może interpretować dźwięki o tak samo zmieniającym się $\mathrm{F}_{\mathrm{o}}$ na oba sposoby. Na przykład w znanej iluzji speech to song (Deutsch, Lapidis i Henthorn 2008; Deutsch, Henthorn i Lapidis 2011) ten sam bodziec akustyczny, który składa się $\mathrm{z}$ zapętlonego fragmentu mowy, interpretowany jest najpierw jako mowa, a później jako śpiew. Chociaż częstotliwości podstawowe dźwięków składających się na prezentowane pętle są za każdym razem takie same, na początku słuchacze interpretują słyszane bodźce jako dźwięki o zmieniającej się wysokości w sposób ciągły, a po pewnym czasie jako następujące po sobie dyskretne klasy wysokości dźwięku. Innym przykładem dwojakiej interpretacji tego samego bodźca akustycznego jest percepcja głosek w słynnym eksperymencie Harry'ego McGurka i Johna MacDonalda (McGurk i MacDonald 1976), w którym te same dźwięki interpretowane są jako różne fonemy $\mathrm{w}$ zależności od prezentowanego jednocześnie $\mathrm{z}$ bodźcem mownym bodźca wizualnego złożonego z obrazu twarzy osoby wypowiadającej różne głoski (zgodne i niezgodne $\mathrm{z}$ prezentowanym bodźcem akustycznym). Tym, co w głównej mierze wpływa na dyskryminację podstawowych dyskretnych segmentów systemu fonologicznego mowy są różne cechy widma akustycznego dźwięku. W językach tonalnych i iloczasowych dodatkowym elementem akustycznym wykorzystywanym do wyróżniania dyskret nych segmentów systemu są też $\mathrm{F}_{\mathrm{o}}$ oraz obiektywny czas trwania dźwięku odpowiednio dla rozpoznania np. tonu leksykalnego (Kaan i wsp. 2008) czy iloczasu (Ylinen i wsp. 2005). Także jednak i w przy padku mowy te same cechy akustyczne mogą zostać zinterpretowane przez układ nerwowy człowieka w różny sposób.

To, w jaki sposób układ nerwowy człowieka interpretuje dźwięki składające się na muzykę lub mowę zależy od wielu czynników. Z neurobiologicznego punktu widzenia o określonej interpretacji bodźca akustycznego decydują cechy anatomiczne narządu słuchu oraz tych struktur układu nerwowego, które zaangażowane są w przetwarzanie informacji muzycznej i mownej. Za sprawą specyficznych cech budowy ludzkiego narządu słuchu oraz innych powiązanych $\mathrm{z}$ tym narządem struktur układu nerwowego obraz mentalny percypowanego przez nasz układ nerwowy bodźca akustycznego jest zniekształcany w sposób charakterystyczny dla naszego gatunku, a nawet grupy społecznej. Na przykład specyficzna dla naszego gatunku budowa kanału słuchowego ucha zewnętrznego powoduje, że w kanale tym zachodzi zjawisko rezonansu dla dźwięków z zakresu od około 3 do 4 kHz, którego skutkiem jest to, że dźwięki z tego zakresu częstotliwości są wzmacniane jeszcze przed dotarciem do błony bębenkowej (Rossing 2007). Dzięki tej i podobnym transformacjom, które dokonują się w dalszych częściach ucha nasze sły szenie dźwięków z zakresu częstotliwości charakterystycznych dla mowy 
Piotr Podlipniak: Cechy systemów fonologicznych muzyki i mowy z perspektywy ewolucyjnej

i śpiewu jest szczególnie wrażliwe w porównaniu do dźwięków spoza tego zakresu częstotliwości. Na interpretację bodźców akustycznych jako mownych bądź muzycznych wpływają ponadto cechy charakterystyczne budowy drogi słuchowej oraz innych struktur mózgowia czlowieka, wśród nich móżdżku, jąder podkorowych oraz kory nowej (Booth i wsp. 2007; Kotz i Schwartze 2010). To, co wyłania się na skutek synergii wszystkich zaangażowanych $\mathrm{w}$ przetwarzanie mowy czy muzyki struktur układu nerwowego człowieka jest jednak obrazem mentalnym uzależnionym zarówno od cech akustycznych, jak i tendencji interpretacyjnych swoistych „mentalnych uprzedzen”" - zakodowany ch i przechowywanych w pamięci układu nerwowego pod postacią określonych wzorców percepcyjnych. W pewnym uproszczeniu, $\mathrm{w}$ procesie percepcji aktywacja sieci, w których zakodowane są owe wzorce następuje wówczas, gdy docierająca do naszego mózgu informacja jest wystarczająca, aby nasz mózg uznal, iz to, co słyszymy jest najbardziej prawdopodobnym fonemem w przypadku słuchania mowy albo klasą wysokości dźwięku w przypadku słuchania muzyki.

Wspomniane tendencje percepcyjne ksztaltują się $\mathrm{w}$ procesie ontogenezy czlowieka $\mathrm{i}$ zależą od wzajemnych interakcji pomiędzy informacją genetyczną, epigenetyczną i tą docierającą do nas ze środowiska (Jablonka i Lamb 2005). Niepoślednią rolę odgrywa tu informacja kulturowa np. statystycznie istotne cechy akustyczne mowy, którą słyszymy podczas dorastania (Romberg i Saffran 2010). Nie można jednak bagatelizować informacji genetycznej, a być może także epigenetycznej, $\mathrm{w}$ procesie nabywania i ksztaltowania wspomnianych tendencji percepcyjnych. Wielu badaczy skłania się dziś do przekonania, że zarówno mowa, jak i muzyka są cześcią gatunkowo specyficznego behawioru Homo sapiens (Berent 2012; Pinker i Jackendoff 2005; Merker 2003; Hauser, Chomsky i Fitch 2002). Jeśli tak, to wspomniane tendencje percepcyjne ksztaltowane są dzięki wyselekcjonowanej w drodze doboru naturalnego informacji genetycznej. Obraz mentalny mowy i muzyki, którego doświadczamy różni się zatem od tego, który doświadczany jest przez inne niż człowiek gatunki zwierząt. Podobnie to, co słyszymy, kiedy słuchamy pieśni ptasich różni się od tego, co słyszą ptaki (Shannon 2016). Systemy fonologiczne mowy i muzyki są zatem w istocie własnościami układów nerwowych ludzi.

\section{Muzyka i mowa a zjawiska konceptualne}

Jedną z charakterystycznych cech ludzkiego poznania jest zdolność do ujmowania percypowanej rzeczywistości w mniej lub bardziej precyzyjne kategorie dostępne naszej świadomości. Niewątpliwie istotną rolę $w$ procesie konceptualizacji postrzeganego czy wyobrażanego świata przez ludzi odgrywa język naturalny. Do niedawna szczególnie popularnym poglądem zwłaszcza $\mathrm{w}$ środowiskach przedstawicieli nauk społecznych i humanistycznych było przekonanie o językowej determinacji postrzeganej przez człowieka rzeczywistości (Boas 1982). Do dziś żywa jest na przykład dyskusja o znaczeniu językowego opisu rzeczywistości dla kategoryzacji 
kolorów (por. np. Kay i McDaniel 1978; Saunders i Van Brakel 1997). Mimo jednak, iż język naturalny odgrywa istotną rolę w kształtowaniu ludzkiej umysłowości i poznania (Wolff i Holmes 2011; Casasanto 2008) wpływ ten nie jest jak się wydaje pozbawiony ograniczeń wynikających ze specyfiki ludzkiej umysłowości dzielonej przez wszystkich ludzi na mocy ich gatunkowej wspólnoty (Dor i Jablonka 2010; Dor i Jablonka 2001). Wiele wskazuje też na to, że zdolność do konceptualizacji rzeczywistości nie jest cechą wyłączną Homo sapiens, a o umiejętność ujmowania rzeczywistości $\mathrm{w}$ kategorie konceptualne podejrzewa się coraz to więcej nieposługujących się językiem naturalnym gatunków zwierząt (Spinozzi 1996; Pepperberg 2012). Także sposób, w jaki konceptualizuje rzeczywistość człowiek może przybierać formy, które z trudem dają się ujmować opisowi językowemu. Niezależnie jednak od tego, jak wielką rolę odgrywa język naturalny w kształtowaniu sfery konceptualnej człowieka, nie ulega wątpliwości, że symbole dźwiękowe, którymi posługujemy się mówiąc odwołują nas do intersubiektywnie uzgodnionych konceptów. Nawet z pozoru niezależne od sfery znaczeniowej formuły gramatyczne niosą ze sobą informacje o cechach konceptualnych (Dor i Jablonka 2001; Dor i Jablonka 2010) np. czy coś jest czynnością czy rzeczą, kto jest sprawcą, a kto adresatem czynności itp. System fonologiczny mowy jest zatem zaprzęgnięty do przekazu treści o charakterze konceptualnym.

Tego samego nie można jednak powiedzieć o systemie fonologicznym muzyki. Mimo że następujące po sobie segmenty muzyczne łączą się w analogiczny jak w języku naturalnym sposób w większe całości, kompozycjonalność ta nie pociąga za sobą kompozycjonalności semantycznej. Próżno szukać w następstwach dźwięków w muzyce relacji pociągających za sobą nawet najprostsze związki znaczeniowe takie jak konfirmacja czy przeczenie, relacje wynikania itp., choć niektóre zestawy dźwięków muzycznych mogą być interpretowane w kategoriach symbolicznych i pośrednio odnosić się do sfery konceptualnej, co może tłumaczyć aktywność podczas słuchania muzyki niektórych struktur mózgowia, które zaangażowane są także w przetwarzanie semantyki języka naturalnego (Koelsch 2005; Steinbeis i Koelsch 2008; Koelsch 2011). Wprawdzie profesjonalni muzycy w różnych kulturach posługują się różnymi konceptami muzycznymi ujmowanymi w kategorie językowe dla opisu relacji pomiędzy następującymi dźwiękami w muzyce np. nazwami interwałów muzycznych, skal, rag, makamów itp. kategorie te mają jednak wyraźnie charakter wtórny wobec pierwotnych doświadczeń towarzyszących percepcji przebiegów muzycznych. Co więcej nabycie tych kategorii wymaga wieloletniej nauki o charakterze eksplicytnym między innymi z wykorzystaniem instrukcji językowych. Być może niektóre $\mathrm{z}$ obserwowanych różnic w lateralizacji przetwarzania muzyki pomiędzy laikami i profesjonalnymi muzykami (Bever i Chiarello 1974; Franklin i Baumgarte 1978; Mazzucchi, Parma i Cattelani 1981; Schweiger i Maltzman 1985; Ono i wsp. 2011; Black, Stevenson i Bish 2017) odzwierciedlają, przynajmniej w części, obecność u profesjonalnych muzyków w ich doświadczeniu muzyki kategorii konceptualnych 
Piotr Podlipniak: Cechy systemów fonologicznych muzyki i mowy z perspektywy ewolucyjnej

powiązanych $\mathrm{z}$ elementami systemu fonologicznego muzyki oraz brak takiego powiązania u laików muzycznych. Biorąc jednak pod uwagę, że mentalne powiązanie elementów systemu fonologicznego muzyki $\mathrm{z}$ kategoriami konceptualnymi nie następuje spontanicznie $\mathrm{w}$ okresie nabywania kompetencji muzycznych przez dzieci, jak ma to miejsce $\mathrm{w}$ przypadku nabywania języka naturalnego, założyć należy, iż system fonologiczny muzyki różni się $\mathrm{w}$ swej naturze pod tym względem od systemu fonologicznego mowy.

$O$ ile zatem $w$ przypadku percepcji mowy $w$ naszym układzie nerwowym następuje $\mathrm{w}$ jakiś sposób mapowanie kategorii fonologicznych na kategorie konceptualne (Hilliard i White 2009), o tyle w przypadku percepcji przebiegu muzycznego brak jest takiego powiązania (Lerdahl 2013). Zamiast tego, następstwa dźwięków przebiegu muzycznego wydają się być powiązane $\mathrm{z}$ subtelnymi doświadczeniami emocjonalnymi. Zarówno następstwo klas wysokości dźwięku zróżnicowane pod względem kontekstu innych klas wysokości dźwięku, jak i różne umiejscowienie poszczególnych wartości rytmicznych $\mathrm{w}$ odniesieniu do pulsu muzycznego wywołują szereg specyficznych reakcji emocjonalnych określanych niekiedy jako qualia (Huron 2006: 162-167; 184-185). Reakcjom tym towarzyszą mierzalne zmiany parametrów fizjologicznych tzw. markerów somatycznych aktywności autonomicznego układu nerwowego (Koelsch i wsp. 2008). Jedną $\mathrm{z}$ konsekwencji doświadczania owych subtelnych stanów emocjonalnych $\mathrm{w}$ odpowiedzi na zmieniającą się strukturę fonologiczną przebiegu muzycznego jest hierarchizacja dźwięków składających się na tę strukturę (Lerdahl i Jackendoff 1983). Na przykład w hierarchii tonalnej dźwięki diatoniczne, czyli należące do skali, na której opiera się dana melodia są odczuwane jako bardziej stabilne niż dźwięki tak zwane dźwięki obce (nienależące do tej skali). Brak stabilności ma tutaj charakter emocjonalny, a percepcja dźwięku obcego prowadzi do mierzalnych reakcji fizjologicznych słuchaczy (Gorzelańczyk i wsp. 2017). Podobnie umiejscowienie dźwięków w czasie przebiegu muzycznego percypowane jest przez ludzi w sposób hierarchiczny (Fitch 2013; London 2012). Fonemy w mowie nie tworzą hierarchii analogicznej do hierarchii tonalnej klas wysokości dźwięku (Berent 2012) czy hierarchii metrorytmicznej (London 2012). Niedopuszczalne następstwo fonemów $\mathrm{w}$ sylabie nie powoduje, że sylaby te są niestabilne $\mathrm{w}$ taki sposób, w jaki niestabilne są dźwięki obce $\mathrm{w}$ percepcji przebiegu muzycznego (Berent 2012: 31). Wprawdzie hierarchizacja obecna jest także $\mathrm{w}$ przebiegach mownych pod postacią hierarchii gramatycznej, ale w tym przypadku jest ona podporządkowana kategoriom konceptualnym, wszak relacje gramatyczne są powiązane ze znaczeniem słów (Hilliard i White 2009).

Poza doświadczeniem emocjonalnym, percepcji przebiegu muzycznego towarzyszą też wrażenia o charakterze motorycznym (Janata i Grafton 2003), które zwykle w różnych kulturach wyrażane są w ekspresji ruchowej podczas tańca (Becker 2004). Zarówno jednak wrażenia emocjonalne, jak i motoryczne mają charakter przedkonceptualny i są starsze ewolucyjnie niż semantyka języka naturalnego. $Z$ tej perspektywy 
podczas percepcji muzyki w naszym układzie nerwowym następuje także mapowanie muzycznych kategorii fonologicznych tyle, że nie na stosunkowo młode ewolucyjnie kategorie konceptualne, ale dużo starsze ewolucyjnie doświadczenia ruchowe i emocjonalne. Ponieważ emocje stanowią stary ewolucyjnie system oceny bodźców i zarazem system motywacyjny kontrolujący sferę ruchową (Panksepp 1998), wspomniane powiązanie stosunkowo młodej ewolucyjnie fonologii muzycznej ${ }^{2} \mathrm{z}$ istniejącymi wcześniej kategoriami przedkonceptualnymi sugeruje odmienność funkcjonalną fonologii muzycznej i mownej.

\section{Muzyka i mowa z perspektywy biologicznej}

Mimo że mowa i śpiew odróżnia się jakościowo od innych form komunikacji wokalnej obserwowanych w przyrodzie nie oznacza to, że wśród wokalizacji innych niż człowiek gatunków zwierząt nie występują zjawiska analogiczne, a niekiedy też homologiczne do elementów występujących w mowie i śpiewie. Wśród najczęściej przywoływanych przykładów analogii śpiewu i mowy są pieśni ptaków (Soha i Peters 2015; Marler i Doupe 2000) i waleni (Payne 2000). Wiele wskazuje też, że niektóre elementy obecnej $\mathrm{w}$ mowie i śpiewie ekspresywnej dynamiki (Merker 2003), określanej także mianem afektywnej prozodii (Zimmermann, Leliveld i Schehka 2013), stanowią homologie zjawisk obserwowanych u wielu gatunków ssaków (niektóre $\mathrm{z}$ tych elementów być może nawet u szerszej grupy ssaków niż naczelne). Występowanie ekspresywnej dynamiki wśród licznej grupy innych niż człowiek gatunków zwierząt, a zarazem jej obecność w mowie i muzyce wskazują, że zarówno mowa jak i muzyka opierają się na wielu różnych mechanizmach o różnym wieku ewolucyjnym. Połączenie mechanizmów o różnym wieku ewolucyjnym w jeden większy, synergiczny, funkcjonalnie odrębny system nie jest niczym zaskakującym biorąc pod uwagę fakt, że w toku ewolucji mózgu człowieka młodsze struktury nadbudowywane były na starsze struktury (Roederer 2003), prowadząc do powstawania nowych narzędzi mentalnych w odpowiedzi na presję selekcyjną środowiska. Taki scenariusz zgodny jest z obowiązującą w ewolucji biologicznej tzw. zasadą „majsterkowania” (ang. tinkering), która polega na integrowaniu istniejących, sprawdzonych rozwiązań w funkcjonalnie nowe systemy charakteryzujące się nowymi własnościami (Jacob 1977). Innymi słowy złożone struktury nie powstają w ewolucji z niczego. Dlatego też mowa i śpiew charakteryzują się do pewnego stopnia elementami obecnymi w wokalizacjach innych gatunków zwierząt (Zimmermann, Leliveld i Schehka 2013). Nie budzi też zdziwienia fakt, że takie mechanizmy jak percepcja kategorialna, uczenie się statystyczne, pamięć robocza i wiele

2 Jak dotąd nie zaobserwowano żadnej formy komunikacji wokalnej opierającej się na sy stemie podobny $m$ do sy stemu fon ologicznego m uzy ki w ekspresji wokalnej szy mpansów (Pan troglodytes) i szy m pansów karłowatych (Pan paniscus), co su geruje, iż muzyka mu siała powstać gdzieś w linii rodowej Homo sapiens już po rozejściu się naszych antenatów od wspólnego przodka z szy m pansami. 
Piotr Podlipniak: Cechy systemów fonologicznych muzyki i mowy z perspektywy ewolucyjnej

innych stanowią nieodłączny element nabywania i posługiwania się zarówno językiem naturalnym, jak i muzyką.

Co wydaje się jednak wyjątkowe dla tych dwóch form komunikacji to to, że obok wspomnianej ekspresywnej dynamiki, która operuje zmianami parametrów w sposób ciągły, mowa i śpiew składają się z jakościowo odmiennych elementów o strukturze dyskretnej (Merker 2003). Jednym z teoretycznych wyjaśnień wspólistnienia tych dwóch form ekspresji $\mathrm{w}$ mowie jest model "podwójnego szlaku” (ang. dual-pathway model), w którym niewerbalne wokalizacje afektywne, włączając w to prozodię mowy, przetwarzane są przez odrębny ewolucyjnie starszy system niż syntaktycznie uporządkowana mowa artykułowana (Ackermann, Hage i Ziegler 2014). Choć model ten wyjaśnia złożoność przetwarzania mowy przez układ nerwowy człowieka, wskazując na różny wiek ewolucyjny różnych komponentów mowy, nie odnosi się w żaden sposób do wspótistnienia elementów ciągłych i dyskretnych w muzyce. Osobnym problemem jest tu też pytanie o to, dlaczego w ogóle istnieją dwa odrębne systemy fonologiczne? Innymi słowy, jaka jest ich historia ewolucyjna i jakie funkcje adaptacyjne pełnią3.

\section{Uwagi o genezie ewolucyjnej systemów fonologicznych mowy i muzyki}

Istnienie $\mathrm{w}$ mowie $\mathrm{i}$ śpiewie elementów wspólnych wspiera te hipotezy genezy muzyki i mowy, które wskazują na istnienie wcześniejszej od mowy i muzyki pierwotnej formy komunikacji wokalnej - muzojęzyka (ang. musilanguage), z której dopiero wyewoluowały mowa i muzyka (Brown 2000; Mithen 2009; Mithen 2006). O ile jednak powstanie zarówno wcześniej ekspresywnej dynamiki, jak i późniejsze nadbudowanie nad nią artykułowanej mowy, czyli w pełni wykształconego systemu fonologicznego mowy wydaje się być racjonalnie wytłumaczalne $\mathrm{w}$ kategoriach korzyści biologicznej, jaką zarówno ekspresywna dynamika jak i mowa dają osobnikom wyposażonym w umiejętność posługiwania się tymi systemami, o tyle powstanie systemu fonologicznego muzyki rodzi poważne trudności przy próbach wskazania takich korzyści. Z jednej strony system fonologiczny muzyki opiera się na dyskretnych kategoriach mentalnych obecnych wyłącznie w mózgach osobników Homo sapiens, dzielących pewną wspólnotę kulturową, a ściślej, żyjących w określonej grupie wystarczająco długo, aby wykształcic wzorce percepcyjne charakterystyczne dla danego języka muzycznego. Fakt ten sugeruje możliwe znaczenie systemu fonologicznego muzyki dla ksztaltowania i podtrzymywania relacji międzyosobniczych $\mathrm{w}$ grupie. Z drugiej strony,

\footnotetext{
3 Dodać należy, że niektór zy współcześni ba dacze skłaniają się do przekonania, że muzy ka nie jest zjawiskiem adaptacyjny $\mathrm{m}$, a obserwowane w muzy ce zjawiska sy ntakty czne są produktem ubocznym in nych zdolności pozna wczych (m.in. zdoln ości językowych), które wy ewolu owały nie będąc pierwotnie częścią ludzkiej muzy czności (Pinker 2002; Patel 2008).
} 
brak ścisłego związku tego systemu ze sferą konceptualną wydaje się podawać w wątpliwość sens ewolucji alternatywnego do mowy systemu komunikacyjnego o mniejszych możliwościach dzielenia się konceptami pomiędzy poszczególnymi osobnikami. Także komunikowanie stanów emocjonalnych innym osobnikom jako funkcja ultymatywna systemu fonologicznego muzyki wydaje się być mało przekonująca zważywszy na filogenetycznie wcześniejsze istnienie ekspresywnej dynamiki, która zdaje się wypełniać tę funkcję wystarczająco skutecznie. Bez trudu rozpoznajemy przecież mowę osoby zirytowanej od osoby przyjaźnie nastawionej do odbiorcy.

Związek systemu fonologicznego muzyki z emocjami nie musi jednak oznaczać, że funkcją tego systemu jest komunikacja stanów emocjonalnych nadawcy. Emocje, jako starszy filogenetycznie od konceptualnego system oceny bodźców (Panksepp 2005; Panksepp 1998), stanowią też alternatywny do konceptualnego rodzaj znaczenia. Jednymi z możliwych komunikatów związanych z doświadczaniem stanów emocjonalnych są informacje, które tylko metaforycznie ująć można w kategorie językowe takie jak: „zagrożenie”, „możliwość jedzenia”, „możliwość reprodukcji”, „możliwość współpracy” itp. Znaczenia te nie są zwykle uświadamiane przez odbiorcę. Zamiast tego uświadamiamy sobie jedynie odczuwane emocje, a czasem nawet emocje nie są koniecznie dostępne naszej świadomości (Damasio 2011). Wielu współczesnych badaczy skłania się do przekonania, że adaptacyjną funkcją muzyki może być jej zdolność do konsolidacji społecznej (Roederer 1984; Storr 1992; Mithen 2006).

Muzyka w różnych kulturach wykorzystywana jest w celach konsolidacyjnych podczas różnego rodzaju obrzędów czy ceremonii, staje się emblematem przynależności do określonych grup społecznych, hymny, pieśni wojenne czy stadionowe zdają się istotnie wpływać na poczucie więzi pomiędzy śpiewającymi wspólnie osobami. Istnieje też coraz więcej badań empirycznych, które zdają się wspierać tę hipotezę (Pearce, Launay i Dunbar 2015; Tarr, Launay i Dunbar 2016; Weinstein i wsp. 2016; Tarr, Launay i Dunbar 2014; Pearce i wsp. 2016). Jeśli faktycznie funkcją muzyki jest konsolidacja grupy emocje towarzyszące następstwom dyskretnych segmentów w przebiegu muzycznym mogłyby być komunikatami o treści „możliwa współpraca”, „zaufany współplemieniec”, „możliwość wsparcia ze strony innych śpiewających”, lub, w przypadku braku zgodności w śpiewie (np. gdy ktoś śpiewa „dźwięk obcy” zamiast diatonicznego), „wątpliwa współpraca”, „osobnik niezaufany”, „wątpliwe wsparcie". Powstanie systemu fonologicznego muzyki byłoby w tym scenariuszu równoznaczne $\mathrm{z}$ wykształceniem się zdolności do rozpoznawania i odczuwania centrum tonalnego (Podlipniak 2016). To właśnie odczucie stabilności centrum tonalnego byłoby ostatecznym komunikatem o współakceptacji społecznej śpiewających gremialnie osobników. Biorąc pod uwagę, że system fonologiczny muzyki powiązany jest ze sferą przedkonceptualną, która jest starsza filogenetycznie niż różne formy konceptualizacji postrzeganej rzeczywistości bardzo 
Piotr Podlipniak: Cechy systemów fonologicznych muzyki i mowy z perspektywy ewolucyjnej

prawdopodobne jest, że system ten jest starszy ewolucyjnie niż system fonologiczny mowy.

Geneza systemu fonologicznego mowy poprzez wyraźne powiązanie ze sferą konceptualną byłaby związana natomiast ze specjalizacją dotyczącą komunikowania określonego rodzaju znaczeń, które z jednej strony są trudne do komunikowania pozawerbalnego, a $\mathrm{z}$ drugiej okazały się ważne $\mathrm{z}$ punktu widzenia doboru naturalnego. Ponieważ istniejący wcześniej system fonologiczny muzyki okazał się niewystarczający do radzenia sobie $\mathrm{z}$ relacjami społecznymi konieczne okazało się powstanie odrębnego złożonego systemu operującego na symbolach dźwiękowych treści referencjalnych. Zdolność do łączenia symboli dźwiękowych z treściami referencjalnymi obecna jest u niektórych innych niż człowiek gatunków zwierząt (por. np. Pepperberg 2012) w tym naszych najbliższych krewnych szympansów (Kalan, Mundry i Boesch 2015; Watson i wsp. 2015), co sugeruje, że homininy, które nie dysponowały jeszcze zdolnością do syntaktycznie złożonej mowy artykułowanej były zdolne do komunikowania treści referencjalnych za pomocą holistycznych wokalizacji (Bickerton 2010). Wydaje się, iż kluczową dla ewolucji komunikacji wokalnej Homo sapiens była wyjątkowa wśród naczelnych (Janik i Slater 1997) zdolność do uczenia się wokalnego (Merker 2005). Dodać należy, że ludzie charakteryzują się szczególną sprawnością $\mathrm{w}$ uczeniu się dźwięków mowy i śpiewu, a nie innych dźwięków słyszanych w otoczeniu (Jackendoff i Lerdahl 2006), co charakteryzuje zdolności niektórych gatunków ptaków (Pepperberg 2012). Kwestią zasadniczą jest to, czy zdolność do uczenia się wokalnego pojawiła się w linii rodowej Homo sapiens jako adaptacja związana $\mathrm{z}$ powstaniem systemu fonologicznego muzyki, czy mowy. W proponowanym tu scenariuszu muzyczny system fonologiczny powstał wcześniej niż system fonologiczny mowy, co zgadza się z tezą o pojawieniu się zdolności do uczenia się wokalnego wraz z powstaniem śpiewu (Merker 2012) - najprostszej formy muzyczności (Morley 2013). Wprawdzie postulat wcześniejszego niż mowa powstania muzyki obecny jest od lat $\mathrm{w}$ dyskursie naukowym (Darwin 1871; Mithen 2006; Harvey 2017), jak dotąd jednak nie ma zgody co do tego jak rozumieć należy pojęcie muzyki. Zaproponowany tu pogląd, który zakłada powstanie systemu fonologicznego muzyki, opierającego się na mentalnych kategoriach klas wysokości dźwięku o określonych wartościach rytmicznych wspierany jest przez fakt, że jedną z ważnych cech zdolności do uczenia się wokalnego czlowieka jest kontrola $F_{o}$, pozwalająca na precyzję intonacyjną oraz kontrola czasu trwania generowanego dźwięku o określonej wysokości w sposób ograniczany jedynie przez konieczność oddychania. Cechy te umożliwiają nie tylko uczenie się wokalne dźwięków muzycznych, ale pozwalają także na wspólnotową synchronizację spektralną śpiewanych dźwięków (por. Bannan 2012). Taka kontrola $F_{o}$ nie jest konieczna dla operowania mową. System fonologiczny mowy powstał zatem $\mathrm{w}$ tym scenariuszu poprzez powiązanie istniejących wcześniej mechanizmów umożliwiających 
operowanie systemem Humboldta w obszarze wokalizacji ze zdolnością do symbolizacji dźwiękowej treści referencjalnych.

\section{Podsumowanie}

Przedstawione powyżej relacje pomiędzy systemami fonologicznymi mowy i muzyki wskazują na ścisły ewolucyjny związek tych dwóch systemów komunikacji wokalnej człowieka. Ważnym krokiem milowym w ewolucji komunikacji wokalnej homininów, która doprowadziła do powstania zarówno mowy jak i śpiewu było pojawienie się komunikacji opartej na synchronizacji stanów mentalnych będących reprezentacjami $o$ charakterze dyskretnym. Dzięki temu możliwe stało się powstanie dwóch niezależnych systemów Humboldta o charakterze intersubiektywnym mowy i śpiewu. Wskazany wyżej szkic scenariusza ewolucyjnego ma oczywiście charakter spekulacyjny, a jego weryfikacja wymaga dalszych badań nad specyfiką mowy i muzyki. Poszerzanie jednak spektrum możliwych scenariuszy ewolucyjnych genezy mowy i śpiewu prowadzi, jak ufam, nie tylko do lepszego rozumienia historii naszego gatunku i tworzenia coraz to nowych strategii weryfikacji empirycznej stawianych tez, ale przyczyni się także do lepszego rozumienia mowy i muzyki jako immanentnych części ludzkiego poznania i zachowania.

\section{Bibliografia}

Ackermann, H., Hage, S. R., Ziegler, W. 2014. Brain Mechanisms of Acoustic Communication in Humans and Nonhuman Primates: An Evolutionary Perspective. Behavioral and Brain Sciences 37 (6): 529-546.

Bannan, N. 2012. Harmony and Its Role in Human Evolution. w: Music, Language, and Human Evolution, edited by Nicholas Bannan, 288-340. Oxford: Oxford University Press.

Becker, J. 2004. Deep Listeners: Music, Emotion, and Trancing. Bloomington: Indiana University Press.

Berent, I. 2012. The Phonological Mind. Cambridge: Cambridge University Press.

Bever, T. G., Chiarello, R. J. 1974. Cerebral Dominance in Musicians and Nonmusicians. Science 185 (4150): 537-539.

Bharucha, J., Curtis, M., Paroo, K. 2011. Musical Communication as Alignment of Brain States. w: P. Rebuschat, M. Rohrmeier, J. A. Hawkins, I. Cross (Eds.) Language and Music as Cognitive Systems, Oxford, New York: Oxford University Press, pp. 139-155.

Bickerton, D. 2010. Adam's Tongue: How Humans Made Language, How Language Made Humans. Hill and Wang.

Bielawski, L. 1968. Muzyka Jako System Fonologiczny. Res Facta 3: 166-171.

Black, E., Stevenson, J. L., Bish, J. P. 2017. The Role of Musical Experience in Hemispheric Lateralization of Global and Local Auditory Processing. Perception 46 (8): 956-975.

Boas, F. 1982. Race, Language, and Culture. University of Chicago Press.

Booth, J. R., Wood, L., Lu, D., Houk, J. C., Bitan, T. 2007. The Role of the Basal 
Piotr Podlipniak: Cechy systemów fonologicznych muzyki i mowy z perspektywy ewolucyjnej

Ganglia and Cerebellum in Language Processing. Brain Research 1133 (1): 136-144.

Brandt, A., Gebrian, M., Slevc, L. R. 2012. Music and Early Language Acquisition. Frontiers in Psychology 3 (SEP): 1-17.

Brown, S. 2000. The 'musilanguage' model of Musical Evolution. w: N. L. Wallin, B. Merker, S. Brown (Eds.) The Origins of Music, Cambridge: The MIT Press, pp. 271-300.

Casasanto, D. 2008. Who's Afraid of the Big Bad Whorf? Crosslinguistic Differences in Temporal Language and Thought. Language Learning 58 (1): $63-79$.

Damasio, A. R. 2011. Bład Kartezjusza : Emocje, Rozum i Ludzki Mózg. Poznań: Dom Wydawniczy "Rebis."

Darwin, Ch. 1871. The Descent of Man, and Selection in Relation to Sex. 1sted. London: John Murray.

Deutsch, D., Dooley, K., Henthorn, T. 2008. Pitch Circularity from Tones Comprising Full Harmonic Series. The Journal of the Acoustical Society of America 124 (1): 589-597.

Deutsch, D., Henthorn, T., Lapidis, . 2011. Illusory Transformation from Speech to Song. The Journal of the Acoustical Society of America 129 (4): 22452252.

Deutsch, D., Lapidis, R., Henthorn, T. 2008. The Speech-to-Song Illusion. The Journal of the Acoustical Society of America 124 (4): 2471.

Dor, D., Jablonka, E. 2001. How Language Changed the Genes: Toward an Explicit Account of the Evolution of Language. w: New Essays on the Origin of Language, 149-176. Berlin, New York: De Gruyter Mouton.

- - . 2010. Plasticity and Canalization in the Evolution of Linguistic Communication: An Evolutionary Developmental Approach. w: R. K. Larson, V. Deprez, H. Y amakido (Eds.) The Evolution of Human Language, Cambridge: Cambridge University Press, pp. 135-147.

Dutton, D. 2009. The Art Instinct: Beauty, Pleasure, and Human Evolution. New York, Berlin, London: Bloomsbury Press.

Fitch, W. T. 2013. Rhythmic Cognition in Humans and Animals: Distinguishing Meter and Pulse Perception. Frontiers in Systems Neuroscience 7 (October): 68.

Fitch, W. T., Jarvis, E. D. 2013. Birdsong and Other Animal Models for Human Speech, Song, and Vocal Learning. w: Language, Music and the Brain, 499539 .

Franklin, E., Baumgarte, R. 1978. Auditory Laterality Effects for Melodic Stimuli Among Musicians and Nonmusicians. Journal of Research in Music Education 26 (1): 48-56.

Gorzelańczyk, E. J., Podlipniak, P., Walecki, P., Karpiński, M., Tarnowska, E. 2017. Pitch Syntax Violations Are Linked to Greater Skin Conductance Changes, Relative to Timbral Violations - The Predictive Role of the Reward System in Perspective of Cortico-subcortical Loops. Frontiers in Psychology 8 (April): $1-11$.

Harvey, A. R. 2017. Music, Evolution, and the Harmony of Souls. Oxford: Oxford University Press.

Hauser, M. D., Chom sky, N., Fitch, W. T. 2002. The Faculty of Language: What Is It, Who Has It, and How Did It Evolve? Science 298 (5598): 1569-1579.

Hilliard, A. T., White, S. A. 2009. Possible Precursors of Syntactic Components in Other Species. w: D. Bickerton, E. Szathmáry (Eds.) Biological Foundations 
and Origin of Syntax, Cambridge, London: The MIT Press, pp. 161-183.

Huron, D. B. 2006. Sweet Anticipation: Music and the Psychology of Expectation. Cambridge, London: The MIT Press.

-—-. 2016. Voice Leading: The Science behind a Musical Art. Cambridge, London: MIT Press.

Jablonka, E., Lamb, M. J. 2005. Evolution in Four Dimensions: Genetic, Epigenetic, Behavioral, and Symbolic Variation in the History of Life. Cambridge, London: MIT Press.

Jackendoff, R., Lerdahl, F. 2006. The Capacity for Music: What Is It, and What's Special about It? Cognition 100 (1): 33-72.

Jacob, F. 1977. Evolution and Tinkering. Science 196 (4295): 1161-1166.

Janata, P., Grafton, S. T. 2003. Swinging in the Brain: Shared Neural Substrates for Behaviors Related to Sequencing and Music. Nature Neuroscience 6 (7): 682-687.

Janik, V. M., Slater, P. J. B. 1997. Vocal Learning in Mammals. Advances in the Study of Behavior 26 (C): 59-99.

Jones, M. R. 2009. Musical Time. w: S. Hallam, I. Cross, M. Thaut (Eds.) The Oxford Handbook of Music Psychology, Oxford, New York: Oxford University Press, pp. 81-92.

Kaan, E., Barkley, Ch. M., Bao, M., Wayland, R. 2008. Thai Lexical Tone Perception in Native Speakers of Thai, English and Mandarin Chinese: An Event-Related Potentials Training Study. BMC Neuroscience 9 (9): 1-17.

Kalan, A. K., Mundry, R., Boesch, Ch. 2015. Wild Chimpanzees Modify Food Call Structure with Respect to Tree Size for a Particular Fruit Species. Animal Behaviour 101: 1-9.

Kay, P., McDaniel, Ch. K. 1978. The Linguistic Significance of the Meanings of Basic Color Terms. Language 54 (3): 610-646.

Koelsch, S. 2005. Neural Substrates of Processing Syntax and Semantics in Music. Current Opinion in Neurobiology 15 (2): 207-212.

- - . 2011. Towards a Neural Basis of Processing Musical Semantics. Physics of Life Reviews 8 (2): 89-105.

Koelsch, S., Kilches, S., Steinbeis, N., Schelinski, S. 2008. Effects of Unexpected Chords and of Performer's Expression on Brain Responses and Electrodermal Activity. PLoS ONE 3 (7).

Kotz, S. A., Schwartze, M. 2010. Cortical Speech Processing Unplugged: A Timely Subcortico-Cortical Framework. Trends in Cognitive Sciences 14 (9): 392399.

Lerdahl, F. 2013. Musical Syntax and Its Relation to Linguistic Syntax. w: M. A. Arbib (Ed.) Language, Music, and the Brain, Cambridge, London: The MIT Press, pp. 257-272.

Lerdahl, F., Jackendoff, R. 1983. A Generative Theory of Tonal Music. Cambridge, London: The MIT Press.

London, J. 2012. Three Things Linguists Need to Know About Rhythm and Time in Music. Empirical Musicology Review 7 (1-2): 5-11.

Marler, P., Doupe, A. J. 2000. Singing in the Brain. Proceedings of the National Academy of Sciences of the United States of America 97 (7): 2965-2967.

Mazzucchi, A., Parma, M., Cattelani, R. 1981. Hemispheric Dominance in the Perception of Tonal Sequences in Relation to Sex, Musical Competence and Handedness. Cortex 17 (2): 291-302.

McGurk, H., MacDonald, J. 1976. Hearing Lips and Seeing Voices. Nature 264 (23/30): 746-748. 
Piotr Podlipniak: Cechy systemów fonologicznych muzyki i mowy z perspektywy ewolucyjnej

Merker, B. 2002. Music: The Missing Humboldt System. Musicae Scientiae 6: 321.

---. 2003. Is There a Biology of Music? And Why Does It Matter? w: C. Kopiez, R. Lehmann, A. C. Wolther, I. Wolf (Eds.) Proceedings of the 5th Triennial ESCOM Conference, Hanover: Hanover University of Music and Drama, pp. 402-405.

- - . 2005. The Conformal Motive in Birdsong, Music, and Language: An Introduction. Annals of the New York Academy of Sciences 1060 (December): 17-28.

---. 2012. The Vocal Learning Constellation. w: N. Bannan (Ed.) Music, Language, and Human Evolution, London: Oxford University Press, pp. 215-260.

Mithen, S. J. 2009. The Music Instinct: The Evolutionary Basis of Musicality. Annals of the New York Academy of Sciences 1169: 3-12.

Mithen, S. J. 2006. The Singing Neanderthals : The Origins of Music, Language, Mind, and Body. Cambridge: Harvard University Press.

Morley, I. 2013. The Prehistory of Music: Human Evolution, Archaeology, and the Origins of Musicality. New York: Oxford University Press.

Okanoya, K. 2013. Finite-State Song Syntax in Bengalese Finches: Sensorimotor Evidence, Developmental Processes, and Formal Procedures for Syntax Extraction. w: J. J. Bolhuis, M. Everaert (Eds.) Birdsong, Speech, and Language: Exploring the Evolution of Mind and Brain, Cambridge, London: MIT Press, pp. 229-242.

Ono, K., Nakamura, A., Yoshiyama, K., Kinkori, T., Bundo, M., Kato, T., Ito, K. 2011. The Effect of Musical Experience on Hemispheric Lateralization in Musical Feature Processing. Neuroscience Letters 496 (2): 141-145.

Opacic, T., Stevens, C., Tillmann, B. 2009. "nspoken Knowledge: Implicit Learning of Structured Human Dance Movement. Journal of Experimental Psychology: Learning, Memory, and Cognition 35 (6): 1570-1577.

Panksepp, J. 1998. Affective Neuroscience: The Foundations of Human and Animal Emotions. New York: Oxford University Press.

- - . 2005. Affective Consciousness: Core Emotional Feelings in Animals and Humans. Consciousness and Cognition 14 (1): 30-80.

Patel, A. D. 2003. Language, Music, Syntax and the Brain. Nature Neuroscience 6 (7): 674-681.

---. 2008. Music, Language, and the Brain. Oxford, New York: Oxford University Press.

Payne, K. 2000. The Progressively Changing Songs of Humpback Whales: A Window on the Creative Process in a Wild Animal. w: N. L. Wallin, B. Merker, S. Brown (Eds.) The Origins of Music. Cambridge, London: MIT Press, pp. 135-150.

Pearce, E., Jacques L., Dunbar, R. I. M. 2015. The Ice-Breaker Effect : Singing Mediates Fast Social Bonding. Royal Society Open Science 2 (10): 1-9.

Pearce, E., Launay, J., van Duijn, M., Rotkirch, A., David-Barrett, T., Dunbar, R. I. M. 2016. Singing Together or Apart: The Effect of Competitive and Cooperative Singing on Social Bonding within and between Sub-Groups of a University Fraternity. Psychology of Music 44 (6): 1255-1273.

Pepperberg, I. M. 2012. Evolution of Communication and Language: Insights from Parrots and Songbirds. w: M. Gibson, K. R. Tallerman (Eds.) The Oxford Handbook of Language Evolution, Oxford: Oxford University Press, pp. 109-119. 
Pinker, S. 2002. Jak Działa Umyst. Warszawa: Ksiazka i Wiedza.

Pinker, S., Jackendoff, R. 2005. The Faculty of Language: What's Special about It? Cognition 95 (2): 201-236.

Podlipniak, P. 2016. The Evolutionary Origin of Pitch Centre Recognition. Psychology of Music 44 (3): 527-543.

Purves, D. 2017. Music as Biology: The Tones We like and Why. Cambridge, London: Harvard University Press.

Rakowski, A. 2009. The Domain of Pitch in Music. Archives of Acoustics 34 (4): 429-443.

Roederer, J. G. 1984. The Search for a Survival Value of Music. Music Perception: An Interdisciplinary Journal 1 (3): 350-356.

- - . 2003. On the Concept of Information and Its Role in Nature. Entropy 5 (1): $3-33$.

Romberg, A. R., Saffran, J. R. 2010. Statistical Learning and Language Acquisition. Cognitive Science 1 (6): 906-914.

Rossing, T. D. 2007. Introduction to Acoustics. w: A. R. Rossing (Ed.) Springer Handbook of Acoustics, New York, NY: Springer New York, pp. 1-6.

Rothenberg, D., Roeske, T. C., Voss, H. U., Naguib, M., Tchernichovski, O. 2014. Investigation of Musicality in Birdsong. Hearing Research 308: 71-83.

Saunders, B. A. C., Van Brakel, J. 1997. Are There Nontrivial Constraints on Colour Categorization? Behavioral and Brain Sciences 20: 167-228.

Schweiger, A, Maltzman, I. 1985. Behavioural and Electrodermal Measures of Lateralization for Music Perception in Musicians and Nonmusicians. Biological Psychology 20 (2): 129-145.

Shannon, R. V. 2016. Is Birdsong More Like Speech or Music? Trends in Cognitive Sciences 20 (4): 245-247.

Soha, J. A., Peters, S. 2015. Vocal Learning in Songbirds and Humans: A Retrospective in Honor of Peter Marler. Ethology 121 (10): 933-945.

Spinozzi, G. 1996. Categorization in Monkeys and Chimpanzees. Behavioural Brain Research 74 (1-2): 17-24.

Stainsby, T., Cross, I. 2008. The Perception of Pitch. w: S. Hallam, I. Cross, M. Thaut (Eds.) The Oxford Handbook of Music Psychology, Oxford, New York: Oxford University Press, pp. 47-58.

Steinbeis, N., Koelsch, S. 2008. Comparing the Processing of Music and Language Meaning Using EEG and fMRI Provides Evidence for Similar and Distinct Neural Representations. PLoS ONE 3 (5): e2226.

Storr, A. 1992. Music and the Mind. New York: Ballantine Books.

Tarr, B., Launay, J., Dunbar, R. I. M. 2016. Silent Disco: Dancing in Synchrony Leads to Elevated Pain Thresholds and Social Closeness. Evolution and Human Behavior 37 (5): 343-349.

-_- 2014. Music and Social Bonding: 'Self-Other' Merging and Neurohormonal Mechanisms. Frontiers in Psychology 5 (SEP): 1-10.

Tillmann, B., Bharucha, J. J., Bigand, E. 2000. Implicit Learning of Tonality: A Self-Organizing Approach. Psychological Review 107 (4): 885-913.

Watson, S. K., Townsend, S. W., Schel, A. M., Wilke, C., Wallace, E. K., Cheng, L., West, V., Slocombe, K. E. 2015. Vocal Learning in the Functionally Referential Food Grunts of Chimpanzees. Current Biology 25 (4): 495-499.

Weinstein, D., Launay, J., Pearce, E., Dunbar, R. I. M., Stewart, L. 2016. Singing and Social Bonding: Changes in Connectivity and Pain Threshold as a Function of Group Size. Evolution and Human Behavior 37 (2): 152-158.

Wolff, P., Holmes, K. J. 2011. "inguistic Relativity. Wiley Interdisciplinary 
Piotr Podlipniak: Cechy systemów fonologicznych muzyki i mowy z perspektywy ewolucyjnej

Reviews: Cognitive Science 2 (3): 253-265.

Ylinen, S., Shestakova, A., Alku, P., Huotilainen, M. 2005. The Perception of Phonological Quantity Based on Durational Cues by Native Speakers, Second-Language Users and Nonspeakers of Finnish. Language and Speech 48 (3): $313-338$.

Zimmermann, E., Leliveld, L., Schehka, S. 2013. Toward the Evolutionary Roots of Affective Prosody in Human Acoustic Communication: A Comparative Approach to Mammalian Voices. w: E. Altenmüller, S. Schmidt, E. Zimmermann (Eds.) Evolution of Emotional Communication: From Sounds in Nonhuman Mammals to Speech and Music in Man. pp. Oxford, New York, 116-132. 